Original Research

\title{
Comparison between the QRMA Measurement with the Anamnesis and the Capillary Blood Glucose Test
}

\section{Muflih Muflih, Suwarsi Suwarsi, and Fajarina Lathu Asmarani}

University of Respati Yogyakarta, Central Java, Indonesia

\section{ABSTRACT}

Introduction: The examination of patients with diabetes mellitus (DM) can be done by reviewing their complaints and through a capillary blood glucose level test to determine the value of their Random Blood Glucose Level. QRMA (Quantum Resonance Magnetic Analyzer) is claimed to be able to check the patient's bodily condition (including blood glucose) with an accuracy of $85 \%$. The purpose of this study was to verify the validity of the QRMA tool and its accuracy by comparing the results of the anamnesis and the examination conducted using the capillary blood glucose test method.

Methods: The research method used was a cross-sectional design. The total sample consisted of 44 respondents in the working area of the Community Health Centers in Yogyakarta with the risk factor being blood sugar level instability. The sampling technique used was purposive sampling. The main variable in this study was the value of the blood sugar level measured based on the coefficient value of the QRMA tool and the value of Random Blood Glucose obtained through the capillary blood glucose test.

Results: The blood glucose value was not correlated significantly with the coefficient value of QRMA. The value of blood glucose when examined alongside the result of the respondent's anamnesis showed there to be a significant difference. The value of the QRMA coefficient when examined against the results from the history of the respondents showed no significant difference. Linear regression showed that the variables of height, body weight, and IMT had a correlation with the QRMA coefficient value.

Conclusion: The QRMA tool was not able to provide a picture of the actual condition of the blood glucose level of the respondents when compared with the results of the anamnesis and the blood glucose value from the capillary blood glucose test. Non-invasive health measurement devices such as QRMA are not used by nurses as a standard for determining the health status of DM patients.

\section{ARTICLE HISTORY}

Received: October 10, 2017

Accepted: January 13, 2020

\section{KEYWORDS}

Anamnesis, blood glucose, QRMA (Quantum Resonance Magnetic Analyzer)

\section{CONTACT}

\section{Muflih $\bowtie$ muflih1986@gmail.com $\doteq$ University of Respati Yogyakarta, Central Java, Indonesia}

Cite this as: Muflih, M., Suwarsi, S., \& Asmarani, F. L. (2019). Comparison between The QRMA Measurement with The Anamnesis and The Capillary Blood Glucose Test. Jurnal Ners, 14(2), 224-230. doi:http://dx.doi.org/10.20473/jn.v14i2.6154

\section{INTRODUCTION}

One of the diseases that pose a global health threat is diabetes mellitus (DM). Diabetes mellitus is a metabolic disease due to pancreatic beta-cell damage or a glucose uptake in the peripheral tissue due to insulin ineffectiveness (Type-2 DM) or a lack of absolute insulin (Type-1 DM) (Tjokroprawiro, 2007). The diagnosis of diabetes mellitus is determined according to the tools used, which currently varies. One of the non-invasive diagnostic tools available is QRMA which can display the coefficient value of the blood sugar level taken. This has not been scientifically tested.

The number of DM patients in the world has increased from 346 million in 2004. It is estimated to have increased by $4.4 \%$ in 2030 (My \& Obese, 2004). Data from the Central Bureau of Statistics (Badan Pusat Statistik/BPS in Indonesia) stated that DM patients in Indonesia in 2003 totaled 13.7 million and that this figure is estimated to reach 20.1 million people in 2030 (Rantung, Yetti, \& Herawati, 2015). Riskesdas data (2018) states that 2\% of Indonesia's population suffers from diabetes mellitus based on 
the doctor's diagnosis at an age $>15$ years in the period 2013 - 2018 (Kemenkes RI, 2018).

Blood glucose monitoring is important in order to control and prevent complications ("WHO guidelines on drawing blood: best practices in phlebotomy," n.d.). Early detection can be done through screening by checking the blood glucose level using a capillary blood glucose test (Handelsman et al., 2015).

The Random Blood Glucose test is often performed on DM patients through an invasive capillary blood glucose test method focused on the fingertips. Based on the tool manual, it is written that the non-invasive QRMA inspection tool can display the results of the glucose coefficient in the blood. It is believed to have an accuracy level of $85 \%$. The results of the measurement done with the QRMA tool cannot be trusted because there is no scientific basis for it. Up until now, no scientific studies have been published stating that this tool is equivalent to the capillary blood glucose test method.

Therefore, the validity of the measurement of the blood glucose level using the QRMA tool should be confirmed by comparing it with the capillary blood glucose test. The comparison of these measurements is expected to provide scientific evidence related to the accuracy of the QRMA tool. Based on the above description, the purpose of this study is to determine the validity of the results produced by the QRMA tool when compared with the results of the anamnesis (when the patient has been diagnosed with DM by a doctor before) and the resulting blood glucose.

\section{MATERIALS AND METHODS}

This research study used a cross-sectional design. This study used both correlational and comparative tests in order to determine the validity of the QRMA tool. The Spearman Rank correlation test was used in order see if there were any changes in the coefficient value of the QRMA test when compared with the blood glucose value. The Mann-Whitney comparative test was used to compare the mean coefficient values of the QRMA tool and blood glucose with the results of the anamnesis. The testing of the normality of the numerical data was done using the Shapiro Wilk test (Table 2).

This research study was carried out in the working area of the Community Health Centers in Yogyakarta in September 2017. The sample in this study consisted of the residents in the working area of the Community Health Centers in Ngemplak II, Depok, Sleman, Yogyakarta. They all had risk factors associated with blood sugar level instability. The sampling technique used was purposive sampling (Figure 1). The main variable of this study was the coefficient of the blood glucose measured using the QRMA tool and the blood glucose value from the capillary blood glucose test method (mg/dl). The confounding variables in this study were gender, age, height, weight, and Body Mass Index (BMI).

QRMA (Figure 2) is a non-invasive medical examination tool that functions to analyze the health

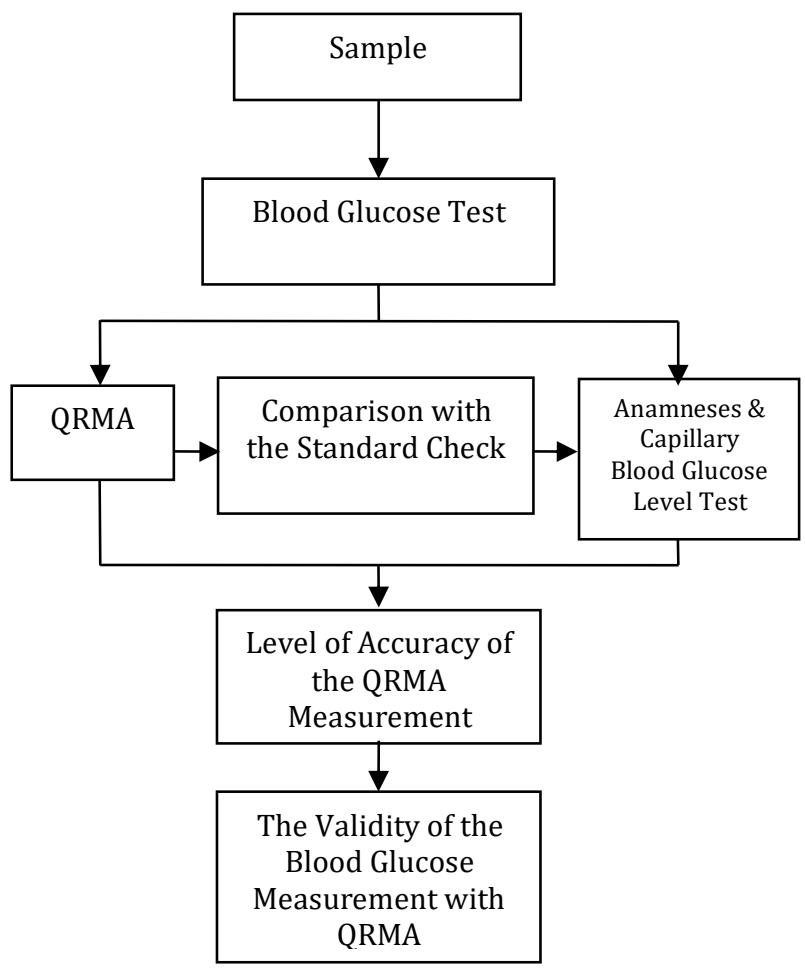

Figure 1. Research Framework

of the internal organs by collecting the body's energy frequency using a magnetic field sensor through a hand grip and electrode sensor. The QRMA tool used in this research was DM-916-C with application version 4.6.0. The use of QRMA began by entering the data for birth time, age, height and weight. The data obtained from the sensor was compared to the health information in the database. This tool takes 1 minute to use with a claimed accuracy of $85 \%$. QRMA will show the blood glucose level and other conditions of the body as well as general advice as a precautionary measure (Figure 3 ).

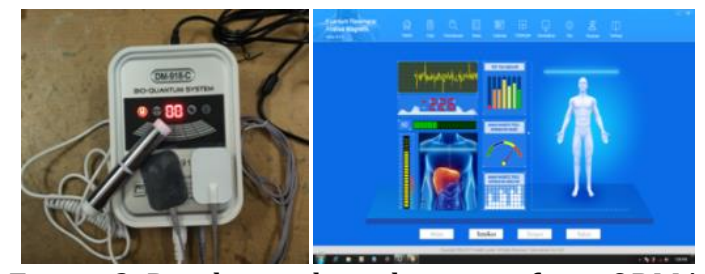

Figure 2. Display tools and screens from QRMA

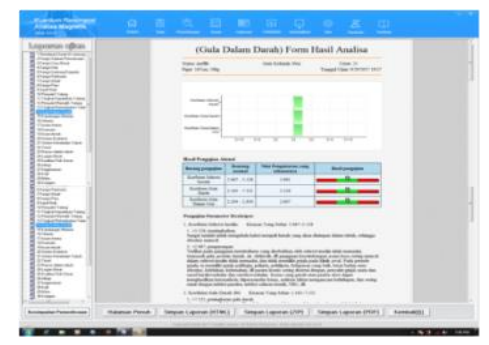

Figure 3. Display of the QRMA analysis results related to blood sugar level 
Table 1. Distribution of Sex and the Results of the Respondent's Anamnesis, 2017 ( $n=44)$

\begin{tabular}{lcc}
\hline Characteristics & f & \% \\
\hline Sex & 33 & 75.0 \\
Female & 11 & 25.0 \\
Male & & 90.9 \\
Anamnesis & 40 & 9.1 \\
No & 4 & \\
Yes
\end{tabular}

Table 2. Distribution of the Age, Height, Weight, BMI, Blood Glucose and QRMA Coefficients, $2017(\mathrm{n}=44)$

\begin{tabular}{lrrrrrrr}
\hline \multirow{2}{*}{ Variables } & \multirow{2}{*}{ Min } & Max & \multirow{2}{*}{ Mean } & \multirow{2}{*}{ SD } & \multicolumn{2}{c}{ CI 95\% } & \multicolumn{2}{c}{$\begin{array}{c}\text { S-W Normality } \\
\text { Test }\end{array}$} \\
\hline Age & 18 & 76 & 45.34 & 13.54 & 41.22 & 49.46 & 0.285 \\
Height & 145 & 171 & 155.09 & 6.38 & 153.15 & 157.03 & 0.001 \\
Weight & 40 & 90 & 56.80 & 10.70 & 53.54 & 60.05 & 0.000 \\
BMI & 17.30 & 35.56 & 23.59 & 4.09 & 22.36 & 24.85 & 0.000 \\
Blood Glucose & 53 & 390 & 127.82 & 57.29 & 110.40 & 145.24 & 0.000 \\
QRMA Coefficient & 2.16 & 7.17 & 4.91 & 1.79 & 4.36 & 5.45 & 0.002 \\
\hline
\end{tabular}

Description: Height in Centimeters; Weight in Kilograms; BMI: Body Mass Index; Random Blood Glucose Level in mg /dl; QRMA Coefficient: Quantum Resonance Magnetic Analyzer Coefficient

Table 3. Correlation between Age, Height, Weight and BMI with Blood Glucose and the QRMA Coefficient, $2017(n=44)$

\begin{tabular}{|c|c|c|}
\hline Variables & Blood Glucose Level & QRMA Coefficient \\
\hline Age & $0.194(0.200)$ & $0.645(0.071)$ \\
\hline Height & $0.478(-0.110)$ & $0.875(-0.024)$ \\
\hline Weight & $0.803(-0.039)$ & $0.838(-0.032)$ \\
\hline BMI & $0.989(-0.002)$ & $0.803(-0.039)$ \\
\hline Blood Glucose & - & $0.316(-0.155)$ \\
\hline
\end{tabular}

Description: P-Value \& (r Value) from Spearman Rank Test; Random Blood Glucose Level in mg /dl

Table 4. Test of the Differences in the Blood Glucose and Coefficient QRMA values with the Results of the Anamnesis, $2017(\mathrm{n}=44)$

\begin{tabular}{|c|c|c|c|c|c|c|c|}
\hline \multirow{2}{*}{ Variables } & \multirow{2}{*}{ Mean } & \multirow{2}{*}{ SD } & \multirow{2}{*}{$\begin{array}{c}\text { Mean } \\
\text { Difference }\end{array}$} & \multirow{2}{*}{ SE Mean } & \multicolumn{2}{|c|}{ CI 95\% } & \multirow{2}{*}{$P$-value* } \\
\hline & & & & & Lower & Upper & \\
\hline \multicolumn{8}{|l|}{ Blood Glucose } \\
\hline Yes & 264.25 & 85.877 & 150.075 & 42.939 & 110.323 & 189.827 & 0.000 \\
\hline No & 114.18 & 30.857 & & 4.879 & & & \\
\hline \multicolumn{8}{|l|}{ QRMA Coefficient } \\
\hline Yes & 4.531 & 1.067 & 0.413 & 0.534 & 2.334 & 1.508 & 0.768 \\
\hline No & 4.944 & 1.861 & & 0.294 & & & \\
\hline
\end{tabular}

Description : *) Mann-Whitney Test

The capillary blood glucose test was chosen because this measurement is a reference for DM patients in the community. Capillary blood glucose testing methods include invasive devices consisting of strips, batteries and a monitor as the main tools used to show the results of the measurements (Niwinski, 2009). The capillary blood test can be performed on the little finger, ring finger or middle finger (Muktabhant et al., 2012). The tool used in this research was an easy touch GCU. Immediate capillary blood glucose measurements were performed after the examination with QRMA. To avoid bias related to the limitations of the tool, the researchers ensured that the tool was a new product and that it worked well. The coefficient value of the blood sugar level from both the QRMA tool and the capillary glucose test were listed on the researcher's note sheet.

\section{RESULTS}

Table 1 shows that the most common sex for the respondents was female (75.0\%). A small proportion were confirmed to have diabetes mellitus (9.1\%).

Table 2 shows that the mean age of the respondents was $13.54 \pm 13.54$ years old (range 1876 years old). The mean value for respondent height was $155.09 \pm 6.38$ centimeters (range 145-171 centimeters). The average value of the respondent's weight was $56.80 \pm 10.70$ kilograms (range 40-90 kilograms). The mean value for the respondent's BMI was $23.59 \pm 4.09$ (range 17.0-35.56). The mean blood glucose value for the respondents was 127.82 $\pm 57.29 \mathrm{mg} / \mathrm{dl}$ (range $53-390 \mathrm{mg} / \mathrm{dl}$ ). The mean value of the QRMA coefficient of the respondents was $4.91 \pm 1.79$ (range $2.15 \pm 7.17$ ). The normality test results showed that only age was normally 
distributed ( $\mathrm{p}$ value $0.285>0.05$ ). The other variables were abnormal (range p value 0.000-0.002<0.05).

Table 3 shows that age ( $p$-value 0.645 ), height ( $p$ value 0.875 ), body weight ( $\mathrm{p}$-value 0.838$)$, BMI ( $\mathrm{p}$ value 0.803 ), and blood glucose (p-value 0.316 ) does not have a significant correlation $(>0.05)$ with the QRMA coefficient value. Similarly, the variables of age (p-value 0.194$)$, body height (p-value 0.803 ), and BMI (p-value 0.989) showed no significant correlation with blood glucose.

Table 4 shows that there was a significant difference between the blood glucose values compared with the respondents' anamnesis (p-value $0.000<0.05$ ). In contrast to the value of the QRMA coefficient, there was no significant difference when it was compared with the results of the respondent's anamnesis ( $p$-value $0.768>0.05$ ). The mean value of blood glucose in the respondents who had a blood glucose problem was $264.25 \pm 85,877$. This is higher than in the respondents who had no blood glucose problem $(114.18 \pm 30,857)$. The mean value of the QRMA coefficient in the respondents who had a blood glucose problem was $4,531 \pm 1,067$, which is lower than that of those who did not have a blood glucose problem at $4,944 \pm 1.861$.

Table 5 shows the results of the multivariate test and the linear regression of sex, age, height, weight, blood glucose, BMI, and the result of the anamnesis with the QRMA coefficient value. The variables with a $p$ value under the alpha value of 0.05 must be removed. In the first stage, the age variable ( $p$-value 0.694 ) issued. In the second stage, the anamnesis variable ( $\mathrm{p}$-value 0.470 ) was issued. The third stage was where the blood glucose variable ( $p$-value 0.440 ) was issued. The fourth stage had the gender variables ( $p$-value 0.124 ) issued. In the fifth stage, the remaining variables of height ( $p$-value 0.044), body weight ( $p$-value 0.040), and BMI (p-value 0.039 ) had $p$-values $<0.05$, so no more variables were issued.

\section{DISCUSSION}

The blood glucose value of the respondents did not correlate significantly with the QRMA coefficient value. The change (increase or decrease) in the respondent's blood glucose value does not follow the same change as the QRMA coefficient value. In the manual, it was described that QRMA does not diagnose disease. It only analyzes the condition of the body based on electromagnetic waves. It is not in direct contact with the blood. The data from the QRMA tool is analyzed related to blood glucose and the results are shown in the form of three coefficient values, namely insulin secretion, blood glucose, and glucose in the urine (Figure 3 ).

In this study, the value used was the coefficient of blood glucose. The normal value range of the blood glucose coefficient via the QRMA device is 2,1637,321 . A coefficient value $>7321$ is considered to show an increase in blood glucose and vice versa, a coefficient $<2.163$ is considered to show a decrease in blood glucose. There was no mention of the usage of frequency $(\mathrm{Hz})$ and wavelength $(\mathrm{Cm})$. In comparison, there are studies on recording electromagnetic wave radiation focused on objects ingested in the human digestive tract done by (Chirwa, Hammond, Member, Roy, \& Cumming, 2003). The study describes the frequency of the wave used as being $150 \mathrm{MHz}$ and $1.2 \mathrm{GHz}$. This is in contrast to the QRMA tool that came with no detailed explanation of the type and mechanism of how electromagnetic waves work in the QRMA tool either in the form of manuals or in published scientific references.

The coefficient value of the measurement of blood glucose level using electromagnetic waves through the QRMA tool has not been explained. There are various types of electromagnetic wave. They are often used to help establish medical diagnoses in the world of health in the form of $\mathrm{X}$ rays (A. Radiasi, Bidang, Untuk, Masyarakat, \& Nuklir-batan, 2008).

The use of electromagnetic waves is also in the form of CT-Scans and Linac therapy.

The use of electromagnetic waves in humans will result in radiation. The absorption rate depends on frequency, wavelength, the electromagnetic field polarization, body spacing compared to the wave source and the electrical properties of the body (P. Radiasi, Elektromagnetik, \& Swamardika, 2009). Complaints resulting from the use of this technology include chronic fatigue, headache, and ringing ears (Kurniawan \& Wahyuni, 2008). Damage to the human body due to electromagnetic waves is due to changes in the balance of free radicals in the biological system (Victorya, 2015).

The Comparison of the QRMA Coefficient and Blood Glucose Values with The Results of The Anamnesis

The comparison between the QRMA coefficient value and the results of the respondent's anamnesis showed there to be no significant difference. This means that the blood glucose problem complained of by the respondents does not match the value of the coefficient from the QRMA. This can be seen from the average value of the lower QRMA coefficients in the respondents who made a high blood glucose complaint. The assessment of the DM patients can be done through interviews related to the trigger factors, signs and symptoms complained of by the respondents (American Diabetes Association, 2014).

The results of the comparison between the blood glucose value with the anamnesis of the respondents showed there to be a significant difference. This means that the changes in blood glucose value are in accordance with the complaints of the respondents related to their blood glucose problems. This can be seen from the average value of the blood glucose being higher in the respondents with blood glucose problems.

The examination of the blood glucose level was done through testing the capillary blood plasma per 
mg / dl unit in accordance with the results of the anamnesis of the client (Rajaratnam \& Pathmanathan, 2011; Hillet al., 2011). This indicates that the early detection of DM can be done through an examination of the blood glucose level via the capillary blood test method (Schifman et al.,2014; Handelsman et al., 2015). The results of the study by (Price, Leary, \& Myburgh, 2005) focused on intensive care clients. The study found that there were statistical similarities between the capillary blood glucose measurements and those from venous blood.

The capillary blood test method is the act of checking or screening for the level of a certain substance in the blood. The accuracy of results is up to $97 \%$ (Kotwal \& Pandit, 2012). Various factors can influence the results of the blood glucose measurements including operator technique, environmental exposure and client factors such as treatment, oxygen therapy, anemia, hypotension, and other disease states (Tonyushkina \& Nichols, 2009). The capillary blood glucose measurement when performed by the client independently is likely to involve a faulty blood sampling procedure resulting in an incorrect data result (Mazze et al., 1994; Montagnana et al., 2009).

The results of the study by Muktabhant et al. (2012) found that the examination of blood glucose and fasting blood glucose through the capillary blood glucose test method still has low sensitivity. Blood glucose measurements using capillary blood samples have been studied by Boyd, Leigh, \& Stuart (2005). They found that there was a small but significant difference between the measurement of capillary blood glucose level and that of venous blood. Similar results were found by Critchell et al. (2007) who stated that the capillary blood glucose level measured through the fingerstick method was not accurate when assessing clients in critical Intensive Care Units (ICUs). The results did not meet the Clinical and Laboratory Standards Institute (CLSI).

Blood glucose examination results from venous blood samples have thus become the most accurate reference available (Holmer, Ogden, Burda, \& Norris, 2013). The measurement of the capillary blood glucose level can be attempted near to where the results of a venous blood sample examination were drawn by warming the hands of the clients before the examination (Hospital, 1992). This is possible because of the effect of arterial vasodilation on the hands of the client.

The examination of blood glucose levels performed in a non-invasive manner is still being developed. The results of a pilot study by Larin, Eledrisi, Motamedi, \& Esenaliev, (2002) suggest that there is a significant correlation between changes in the non-invasive Optical Coherence Tomography (OCT) signals with the concentration of blood glucose during the trial.

\section{Variables of Height, Weight and BMI are The Determinants of QRMA Coefficient}

The results of the multivariate linear regression test showed that the variables of height, weight, and BMI have a correlation with the QRMA coefficient value (Table 5). This means that the three variables are the determinants, while blood glucose level and the results of the anamnesis are not in accordance with the value of the coefficient for QRMA.

This proves that DM is a metabolic disease that is hereditary, characterized by hyperglycemia and glycosuria and accompanied by or where there is the absence of acute or chronic clinical symptoms (C. P. Guideline, n.d.). DM as a result of a lack of effective insulin in the body is a primary disorder that lies in the metabolism of carbohydrates that is usually accompanied by disorders related to fat and protein metabolism (H. C. Guideline, 2014). The fat and protein conditions were estimated from the ratio of height, weight, and BMI.

Blood glucose levels are found to be influenced by both endogenous and exogenous factors (Tirimacco et al., 2010). The endogenous factors refer to the hormonal factors such as insulin, glucagon, cortisol and the receptor system in the muscle and liver cells. The exogenous factors include the type and amount of food consumed and the level of physical activity performed.

\section{CONCLUSION}

The limitation in this study was that it did not measure the last time that the respondents had a meal. This meal has an impact on the respondent's blood glucose level.

The QRMA tool does not provide an accurate picture of the blood glucose levels of the respondents compared with the results of anamnesis and the blood glucose values determined through the capillary blood glucose test. The change in the respondent's blood glucose value did not follow the same change in the QRMA coefficient value. The problem of blood glucose complained of by the respondents did not match the value of the QRMA coefficient. The variables of height, weight and BMI are the determinants of QRMA.

\section{ACKNOWLEDGMENT}

We give our thanks to the Ministry of Research, Technology and the University of the Republic of Indonesia for funding and supporting the implementation of this research

\section{REFERENCES}

American Diabetes Association. (2014). Diagnosis And Classification Of Diabetes Mellitus. Diabetes Care, 37((Supplement 1) January), S81-S90. Https://Doi.Org/10.2337/Dc14-S081

Boyd, R., Leigh, B., \& Stuart, P. (2005). Capillary Versus Venous Bedside Blood Glucose Estimations. Emergency Medicine Journal, 22(3), 
177-179.

Https://Doi.Org/10.1136/Emj.2003.011619

Chirwa, L. C., Hammond, P. A., Member, S., Roy, S., \& Cumming, D. R. S. (2003). Electromagnetic Radiation From Ingested Sources In The Human Intestine Between $150 \mathrm{Mhz}$ And 1. 2 Ghz. IEEE Transactions On Biomedical Engineering, 50(4), 484-492.

Critchell, C. D., Savarese, V., Callahan, A., Aboud, C., Jabbour, S., \& Marik, P. (2007). Accuracy Of Bedside Capillary Blood Glucose Measurements In Critically Ill Patients. Intensive Care Medicine, 33(12), 2079-2084. Https://Doi.Org/10.1007/S00134-007-0835-4

Handelsman, Y., Bloomgarden, Z. T., Grunberger, G., Umpierrez, G., Zimmerman, R. S., Bailey, T. S., ... Zangeneh, F. (2015). American Association Of Clinical Endocrinologists And American College Of Endocrinology - Clinical Practice Guidelines For Developing A Diabetes Mellitus Comprehensive Care Plan - 2015. Endocrine Practice, 21((Suppl 1) April), 1-87.

Hill, N. R., Oliver, N. S., Choudhary, P., Levy, J. C., Hindmarsh, P., \& Matthews, D. R. (2011). Normal Reference Range For Mean Tissue Glucose And Glycemic Variability Derived From Continuous Glucose Monitoring For Subjects Without Diabetes In Different Ethnic Groups. Diabetes Technology \& Therapeutics, 13(9), 921-928.

Holmer, H. K., Ogden, L. A., Burda, B. U., \& Norris, S. L. (2013). Quality Of Clinical Practice Guidelines For Glycemic Control In Type 2 Diabetes Mellitus. Plos One, 8(4), 1-6. Https://Doi.Org/10.1371/Journal.Pone.0058625

Kemenkes RI. (2018). Hasil utama RISKESDAS 2018. Jakarta: Kementrian Kesehatan Badan Penelitian dan Pengembangan Kesehatan.

Kotwal, N., \& Pandit, A. (2012). Variability of Capillary Blood Glucose Monitoring Measured On Home Glucose Monitoring Devices. Indian J Endocrinol Metab, 16(Supplement 2), 248-251.

Kulkarni, A., Saxena, M., Price, G., O'Leary, M. J., Jacques, T., \& Myburgh, J. A. (2005). Analysis Of Blood Glucose Measurements Using Capillary And Arterial Blood Samples In Intensive Care Patients. Intensive Care Medicine, 31(1), 142-145. Https://Doi.Org/10.1007/S00134-004-2500-5

Kurniawan, B., \& Wahyuni, I. (2008). Hubungan Radiasi Gelombang Elektromagnetik Dan Faktor Lain Dengan Keluhan Subyektif Pada Tenaga Kerja Industri Eletronik GE Di Yogyakarta. Jurnal Promosi Kesehatan Indonesia, 3(2), 127-133.

Larin, K. V., Eledrisi, M. S., Motamedi, M., \& Esenaliev, R. O. (2002). Noninvasive Blood Glucose Monitoring With Optical Coherence Tomography. Diabetes Care, 25(12), 2263-2267.

Liu, D., Moberg, E., Kollind, M., Lins, P. E., Adamson, U., \& Macdonald, I. A. (1992). Arterial, Arterialized Venous, Venous And Capillary Blood Glucose Measurements In Normal Man During Hyperinsulinaemic Euglycaemia And Hypoglycaemia. Diabetologia, 35(3), 287-290.
Management Of Diabetes Mellitus Update Working Group. (2010). VA/Dod Clinical Practice Guideline For The Management of Diabetes Mellitus (Version 4.). Washington.

Mazze, R. S., Ph, D., Pasmantier, R., Lucido, D., Ph, D., Murphy, J., ... Ph, D. (1994). Reliability Of Blood Glucose Monitoring By Patients With Diabetes Mellitus, 77(August), 211-217.

Montagnana, M., Caputo, M., Giavarina, D., \& Lippi, G. (2009). Overview On Self-Monitoring Of Blood Glucose. Clinica Chimica Acta, 402(1-2), 7-13.

Muktabhant, B., Sanchaisuriya, P., Sarakarn, P., Tawityanon, W., Trakulwong, M., Worawat, S., \& Schelp, F. P. (2012). Use Of Glucometer And Fasting Blood Glucose As Screening Tools For Diabetes Mellitus Type 2 And Glycated Haemoglobin As Clinical Reference In Rural Community Primary Care Settings Of A Middle Income Country. BMC Public Health, 12(1), 349.

Niwinski, N. (2009). Capillary Blood Collection: Best Practices. Labnotes, 20(1), 1-8.

Rajaratnam, H. N., \& Pathmanathan, S. (2011). How Reliable Are Capillary Blood Glucose Measurements? Sri Lanka Journal of Diabetes Endocrinology And Metabolism, 1(1), 22-24.

Rantung, J., Yetti, K., \& Herawati, T. (2015). Hubungan Self-Care Dengan Kualitas Hidup Pasien Diabetes Melitus (Dm) Di Persatuan Diabetes Indonesia (Persadia) Cabang Cimahi. Jurnal Skolastik Keperawatan, 1(1), 38-51.

Redmon, B., Caccamo, D., Flavin, P., Michels, R., O'Connor, P., Roberts, J., ... Sperl-Hillen, J. (2014). Diagnosis And Management Of Type 2 Diabetes Mellitus In Adults. Institute For Clinical Systems Improvement, 16(7), 1-85.

Schifman, R. B., Nguyen, T. T., \& Page, S. T. (2014). Reliability of Point-Of-Care Capillary Blood Glucose Measurements In The Critical Value Range. Archives of Pathology And Laboratory Medicine, 138(7), 962-966.

Suyatno, F. (2008). Aplikasi Radiasi Sinar-X Di Bidang Kedokteran Untuk Menunjang Kesehatan Masyarakat. In Seminar Nasional IV SDM Teknologi Nuklir (Pp. 25-26). Yogyakarta.

Swamardika, I. B. A. (2009). Pengaruh Radiasi Gelombang Elektromagnetik Terhadap Kesehatan Manusia. Majalah Ilmiah Teknologi Elektro, 8(1).

Tirimacco, R., Tideman, P. A., Dunbar, J., Simpson, P. A., Philpot, B., Laatikainen, T., \& Janus, E. (2010). International Journal of Diabetes Mellitus Should Capillary Blood Glucose Measurements Be Used In Population Surveys? International Journal of Diabetes Mellitus, 2(1), 24-27. Https://Doi.Org/10.1016/J.Ijdm.2009.12.002

Tjokroprawiro, A. (2007). Buku Ajar Ilmu Penyakit Dalam. Surabaya: Airlangga University Press.

Tonyushkina, K., \& Nichols, J. H. (2009). Glucose Meters: A Review Of Technical Challenges To Obtaining Accurate Results, 3(4).

Victorya, R. M. (2015). Effects Of Handphone ' S Electromagnetic Wave Exposure On Seminiferous Tubules. Jurnal Majority, 4(3). 
MUFLIH ET AL.

WHO. (2010). WHO guidelines on drawing blood : best practices in phlebotomy. Genewa: WHO Document Production Services.

Wild, S. H., Roglic, G., Green, A., Sicree, R., \& King, H. (2004). Global prevalence of diabetes: estimates for the year 2000 and projections for 2030: response to Rathman and Giani. Diabetes Care, 27(10), 2569. 